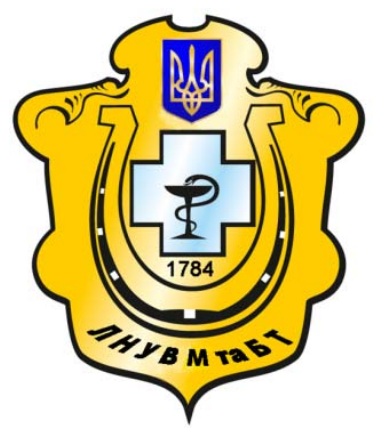

Науковий вісник Львівського національного університету ветеринарної медицини та біотехнологій імені С.3. Гжицького

Scientific Messenger of Lviv National University of Veterinary Medicine and Biotechnologies named after S.Z. Gzhytskyj

doi:10.15421/nvlvet7734

ISSN 2518-7554 print

ISSN 2518-1327 online

$\underline{\text { http://nvlvet.com.ua/ }}$

УДК 619. 477

\title{
Паростки лікувальної справи тварин в Галичині
}

\author{
В.Я. Присяжнюк \\ Vasyl.prysyaznyuk@gmail.com
}

Львівський національний університет ветеринарної медицини та біотехнологій імені С.3. Гжицького, вул Пекарська,50, м. Львів,79010, Украӥна

\begin{abstract}
Народна ветеринарія - важлива ділянка народного досвіду, що містить раціональні знання та практичні навики лікування свійських тварин. Особливу увагу украйниі приділяли тим тваринам, від яких залежсало успішне ведення господарства (коні, велика рогата худоба, свині, вівиі). У народній ветеринарії використовувались в основному ті ж засоби, що $і$ в народній медицині. Найпопулярнішими були ліки рослинного походження. Часто рослинні ліки використовувалися у поєднанні $з$ мінеральними речовинами, тваринними жирами. Народна ветеринарія нагромадила і певні знання про значення санітарії та гігієни для успішного догляду за свійськими тваринами. Для профілактики захворювань тварин не тримали у вогких чи холодних місиях, не давали пити застояну воду, періодично змінювали місце випасу і водопою, стежили за своєчасним підковуванням коней $і$ волів. Під час війн у коней спостерігалися різні рани, нанесені холодною зброєю, забої, розтяги, травми тошо. Лікували иі рани вершники, використовуючи методи і засоби народної медицини. Для перев'язування травмованих кінцівок, а також як кровозупинні речовини використовували сухі й попередньо прокип'ячені овечу шерсть, грубе полотно, дьоготь, попіл, різні лікарські речовини та інші засоби. Після закінчення військових дій лікуванням травм у коней займалися народні иілителі, знахарі, а в основному - коновали, особливу увагу звертали на повноцінну годівлю, догляд за шкірним покривом, копитами. Пастухам було відомо і про заразні хвороби, яким вони намагалися запобігти $i$ лікувати їх, а також хвороби вимені, органів травлення і дихання. Пастухи намагалися найрізноманітнішими способами лікувати і паразитарні захворювання. Наприклад, фасціольоз (мотилицю) вони лікували галузками смереки, конопляним насінням, підсмаженим вівсом. Пастухи, скотарі, знахарі збирали, сушили, зберігали і застосовували лікарські трави при родах $і$ травмах, вони займалися також кровопусканням. Для лікувальних цілей використовували кров, жир, жовч, кістковий мозок, молоко $і$ молочні продукти, рослинні олії, тобто саме вони були першими ветеринарними фахівияли-лікарями. Велику роль в житті та побуті львівського міщзанства відігравали хірурги-цирульники. Вони займались лікуванням, виготовляли ліки, пластирі, пускали кров, а також стригли і голили. Велика увага приділялася охороні людей від заразних захворювань.

Ключові слова: народна ветеринарія, захворювання, коновали, пастухи, лікарські заходи, хірурги-цирульники, діагностика, ветеринарна служба, тварини, епізоотії.
\end{abstract}

\section{Истоки лечебного дела животных в Галичине}

\author{
В.Я. Присяжнюк \\ Vasyl.prysyaznyuk@gmail.com
}

Львовский национальный университет ветеринарной медицины и биотехнологий имени С.3. Гжицкого, ул. Пекарская, 50, г. Львов, 79010, Украина

Народная ветеринария - важная область народного опыта, которая содержит рациональные знания и практические навыки лечения домашних животных. Особенное внимание украинцы уделяли тем животным, от которых зависило успешное ведение хазяйства (лошади, крупный рогатый скот, свиньи, овиы). В народной ветеринарии использовались в основном те же средства, что и в народной медицине. Наиболее употребляемыми были лекарства растительного происхождения. Часто они использовались в сочетании с минеральными веществами, животными жсирами. Народная ветеринария накопила некоторый опит о значении санитарии и гигиены для успешного ухода за животными. Чтобы предотвратить заболевания, животных не держали во влажных или холодних местах, не давали им пить застоянную воду, периодически меняли

Citation:

Prysjazhnjuk V. (2017). Sprouts of animals medical affairs in Galychyna. Scientific Messenger LNUVMBT named after S.Z. Gzhytskyj, 19(77), 158-161. 
места выпасания и водопоя, следили за своевременным подковыванием лошадей и волов. Во время войн у лошадей наблюдали разные раны, нанесенные холодным оружием, забои, растяжения, травмы. Лечили эти раны всадники, используя методы и средства народной медицины. Для перевязки травмированных конечностей, а также в качестве кровеостанавливающчих средств использовали сухие и предварительно прокипяченные овечью шерсть, грубое полотно, деготь, пепел, разные лекарственные средства и другие вещества. По окончании военных действий лечением травм у лошадей занимались народне цуелители, знахари, а в основном - коноваль, особое внимание обращули на полноценное кормление, уход за кожным покровом, копьтами. Пастухам было известно и о заразных болезнях, которые они старались предупредить и лечить, а также болезни вымени, органов пищеварения и дыхания. Пастухи старались разными способами лечить и паразитарне болезни. Например, фасциолез они лечили ветками ели, конопляными семенами, поджаренным овсом. Пастухи, скотники, знахари собирали, сушили, сохраняли и использовали лечебные травы при родах, травмах, они занимались также кровопусканием. Для лечебных целей использовали кровь, жир, желчь, костный мозг, молоко и молочные продукты, растительные масла, то есть они были первыми ветеринарними специалистами-врачами. Большую роль в жизни и быте львовского мещуанства играли хирурги-цырульники. Они занимались лечением, изготовлением лекарств, пластьрей, пускали кровь, а также стригли и брили. Большое внимание уделялось охране людей от заразних болезней.

Ключевые слова: народная ветеринария, заболевания, коноваль, пастухи, лечебные мероприятия, хирурги-иьырульники, диагностика, ветеринарная служба, животные, эпизоотии.

\title{
Sprouts of animals medical affairs in Galychyna
}

\author{
V. Prysjazhnjuk \\ Vasyl.prysyaznyuk@gmail.com \\ Lviv National University of Veterinary Medicine and Biotechnologies named after S.Z. Gzhytskyj, \\ Pekarska str., Lviv, 50, 79010, Ukraine
}

Folk veterinary medicine - an important plot of national experience, which includes rational knowledge and practical skills of domestic animals treatment. The special attention was paid to those Ukrainian animals from whom was depended the success of farming (horses, cattle, pigs, sheep). In traditional veterinary medicine are mainly used the same means as in folk medicine. The most popular were the drugs of plant origin. Frequently herbal medicine is used in combination with minerals, animal fats. Folk veterinary accumulated and some knowledge about the importance of sanitation and hygiene for the successful care for domestic animals. To prevent diseases animals were kept in damp or cold places, did not allow to drink stagnant water, periodically changed grazing and watering place, followed by timely horses forging and oxen. During the wars there were observed various wounds in horses, applied with edged weapons, slaughter, stretching, injuries and more. Those wounds were treated by horsemen, using methods and traditional medicines. For bandaging the injured limb, as well as the blood stops substances are used dry and pre-boiled wool, rough canvas, tar, ash, various drugs and other means. After the end of hostilities the treatment of injuries in horses were engaged healers, chiropractors, but mostly - horse doctor, paying particular attention to the full feed, care of the skin, hooves. The shepherd had known about infectious diseases, which they tried to prevent and treat, and diseases of the udder, digestive and respiratory system. The shepherds tried in various ways to treat and parasitic diseases. For example, Fasciolosis (rot) they treated with fir branches, hemp seed, toasted oats. Shepherds, herdsmen, healers collected, dried, stored and used medicinal herbs during genera and injuries, they were also engaged in bloodletting. For therapeutic purposes blood fat, bile, bone marrow, milk and dairy products, vegetable oils were used, to wit they were the first veterinary specialists doctors. Itinerant surgeons-barbers were also engaged in treatment of animals. In the twelfth century. surgeons-barbers moved to sedentary lifestyles and became to join into craft, which were engaged in the treatment of sick animals and training of young professionals. Barbers surgeons played great role in life and everyday life of the Lviv philistinism. They were engaged in treatment, produced drugs, patches, bled and also sheared and shaved.

Key words: folk medicine, illness, farrier, shepherds, medical measures, surgeons, barbers, diagnostics, veterinary service, animals, epizootic.

\section{Вступ}

Актуальність теми Впродовж останніх років опубліковано цілу низку наукових досліджень вітчизняних авторів (Kis, 1968; Verkhratskyi and Zabludovskyi, 1991; Verbytskyi et al., 2002), присвячених історії медицини, що розкриває питання зародження, становлення та розвитку лікувальної справи, в тому числі у різних регіонах України залежно від політичних $\mathrm{i}$ соціально-економічних умов. У значній кількості наукових праць показано організацію і становлення державної ветеринарної служби певного краю, області (Aranchii, 1998; Sadvari et al., 2000; Rudyk and Bisiuk, 2000; Kurtiak and Tkachuk, 2001; Sytarchuk, 2002; Verbytskyi et al., 2002).

Мета дослідження: висвітлити питання діяльності фахівців лікувальної справи 3 метою недопущення захворювань та лікування тварин в певних історичних умовах в Галичині. Завдання дослідження полягали в тому, щоб отримати дані щодо організації роботи фахівців лікувальної справи тварин у давні часи в Галичині, їхню діяльність 3 метою зменшення захворюваності тварин і людей, діагностики хвороб, застосування лікувальних засобів при різних захворюваннях, профілактики заразних хвороб тварин на території західноукраїнських земель.

\section{Матеріал і методи досліджень}

Матеріалом для вивчення лікувальної справи тварин на західноукраїнських землях послужили окремі архівні документи державного історичного архіву в м. Львові, періодичні видання, статті, а також деякі вітчизняні та іноземні літературні джерела Національної наукової бібліотеки імені В. Стефаника НАН України у м. Львові. При проведенні досліджень ви- 
користано методи: хронологічний, системний, порівняльно- історичний, аналітичний.

\section{Результати та їх обговорення}

Ветеринарна медицина в найдавніші часи в Україні була чисто емпіричною, або народною, практикою. Народна ветеринарія - важлива ділянка народного досвіду, що містить раціональні знання та практичні навики лікування свійських тварин. Особливу увагу українці приділяли тим тваринам, від яких залежало успішне ведення господарства (коні, велика рогата худоба, свині, вівці).

У народній ветеринарії використовувались в основному ті ж засоби, що і в народній медицині. Найпопулярнішими були ліки рослинного походження. Так, при розладах травлення у тварин їх напували відварами деревію, кмину, звіробою, дубової кори, а при затвердіннях шлунка давали пити відвар із насіння льону. Невеликі рани лікували соком або товченим листям ранника, промивали відваром чебрецю, живокосту, ромашки. Шкірні захворювання та висипки лікували водяним відваром тютюну, гірчака, а також домашнім квасом та дьогтем.

Часто рослинні ліки використовувалися у поєднанні з мінеральними речовинами, тваринними жирами. Худобу від сибірської виразки лікували домашнім квасом, змішаним із селітрою та нашатирним спиртом. Тварин, хворих на чумку, напували відваром на буряковому квасі насіння льону, конопель, зернових із додатком заліза, дьогтю, часнику і мідного купоросу. Для зниження температури тіла худобу змащували розчином рудої глини, буряковим квасом. Мідний купорос використовували також для лікування такого поширеного захворювання тварин, як ящур. При здутті тварин від перегодовування їх напували огірковим розсолом або олією, закріплювали в роті солом'яне перевесло і проганяли до сильного спітніння. Подекуди при цьому заганяли тварин у воду на кілька годин, а іноді проводили кровопускання.

Народна ветеринарія нагромадила і певні знання про значення санітарії та гігієни для успішного догляду за свійськими тваринами. Для профілактики захворювань тварин не тримали у вогких чи холодних місцях, не давали пити застояну воду, періодично змінювали місце випасу і водопою, стежили за своєчасним підковуванням коней і волів.

Вже в ті далекі часи серед людей виділялися окремі групи, що спеціалізувалися на лікуванні ран, пусканні крові, допомозі при родах, переломах кінцівок тощо. Зростання чисельності населення і тварин викликало зростання попиту на лікувальну допомогу, що в свою чергу сприяло виокремленню певної кількості осіб, для яких лікувальна справа ставала основною професією. В основному знання цих фахівців лікувальної справи базувалися на досвіді народної медицини 3 елементами містичного характеру, що обумовлювалося тогочасним світоглядом.Часті війни, переміщення великої кількості людей, тварин приводили до спалахів епізоотій та епідемій.

Під час війн у коней спостерігалися різні рани, нанесені холодною зброєю, забої, розтяги, травми тощо.
Лікували ці рани вершники, використовуючи методи і засоби народної медицини. Для перев'язування травмованих кінцівок, а також як кровозупинні речовини використовували сухі й попередньо прокип'ячені овечу шерсть, грубе полотно, дьоготь, попіл, різні лікарські речовини та інші засоби.

Після закінчення військових дій лікуванням травм у коней займалися народні цілителі, знахарі, а в основному - коновали, особливу увагу звертали на повноцінну годівлю, догляд за шкірним покривом, копитами.

Про ветеринарію в той час знали мало, вона носила емпіричний характер уявлень про хвороби тварин, хоч її корені тягнуться в далекі минулі часи.

В ті часи всі заходи проти пошестей і лікування тварин тримались на народній ветеринарній медицині. Надання допомоги тварині під час захворювання вже свідчило про зародження ветеринарії. Усували ці хвороби домашніми, цілком простими засобами, такими як рум'янок, цвіт чорної бузини, льняне насіння, олія, полин, ягоди ялівцю, дубова кора, гірчиця, сіль, мідний купорос на ін. Серед інструментів, які застосовували при хворобах, на цей час були пущадла i троакар. Рекомендувалися ліки у формі порошків, заливань, вдихання пари, натирання.

У XI-XV ст. лікуванням тварин все частіше почали займатися конюхи, пастухи, народні цілителі, знахарі, волхви. 3 розвитком тваринництва власники тварин та члени їх сімей стають одночасно і пастухами, і ветеринарами, які вміли допомагати тваринам при незначних ушкодженнях і хворобах, доглядати їх під час пологів. Вони вміли стежити за здоров'ям тварин, визначати хворобу і надавати тваринам посильну лікувальну допомогу. Господарі та пастухи добре усвідомлювали, що з метою запобігання захворюванням тварин необхідно утримувати у чистоті, добре годувати, випасати тільки на сухих пасовищах.

Діагностика захворювань у той час базувалася, в основному, лише на використанні власних органів чуттів: досліджували рух тварин, температуру тіла, колір очей, стан язика, носового дзеркальця, ротової та носової порожнини, видалення поту, сечі, запах 3 рота, ніздрів тощо.

Пастухам було відомо і про заразні хвороби, яким вони намагалися запобігти і лікувати їх, а також хвороби вимені, органів травлення і дихання. Пастухи намагалися найрізноманітнішими способами лікувати і паразитарні захворювання. Наприклад, фасціольоз (мотилицю) вони лікували галузками смереки, конопляним насінням, підсмаженим вівсом.

Пастухи, скотарі, знахарі збирали, сушили, зберігали і застосовували лікарські трави при родах і травмах, вони займалися також кровопусканням. Для лікувальних цілей використовували кров, жир, жовч, кістковий мозок, молоко і молочні продукти, рослинні олії, тобто саме вони були першими ветеринарними фахівцями-лікарями.

Лікуванням тварин займалися також мандрівні хірурги-цирульники.

Велику роль в житті й побуті львівського міщанства відігравали хірурги-цирульники. Вони займались лікуванням, виготовляли ліки, пластирі, пускали кров, а також стригли і голили. Цирульники згадуються у 
Львові вже в XV ст. У 1578 р. тут було засновано цех цирульників.

\section{Висновки}

1. Першими фахівцями лікувальної справи тварин у давні часи в Україні, зокрема в Галичині були пастухи, скотарі, вівчарі, коновали, а згодом - хірургицирульники.

2. Для лікування тварин широко використовували народні засоби рослинного і тваринного походження.

3. Діагностика захворювань в той час базувалася в основному на використанні власних органів чуттів.

4. Були розроблені заходи, спрямовані на запобігання виникненню та поширенню захворювань тварин і людей.

Перспективи подальших досліджень. Планується дослідити створення науково-практичних ветеринарних товариств та їхню роль у розвитку лікувальної справи і тваринництва в Галичині.

\section{Бібліографічні посилання}

Aranchii, S.V. (1998). Istoriia veterynarnoi medytsyny Poltavshchyny. Poltava. Poltavskyi literator (in Ukrainian).

Verbytskyi, P.I., Dostoievskyi, P.P., Rudyk, S.K. (2002). Istoriia veterynarnoi medytsyny Ukrainy. K. Vetinform (in Ukrainian).

Verkhratskyi, S.A., Zabludovskyi, P.Iu. (1991). Istoriia medytsyny. Kyiv (in Ukrainian).

Sadvari, Yu.Iu., Bakhtyn, V.F., Dudash, A.V. (2000). Veterynarna medytsyna Zakarpattia na mezhi tysiacholit. Uzhhorod. Patent (in Ukrainian).

Kis, Ya.P. (1968). Promyslovist Lvova u period feodalizmu. Lviv (in Ukrainian).

Kurtiak, B.M., Tkachuk, P.S. (2001). Narys istorii veterynarnoi medytsyny Lvivshchyny. Lviv. Triada plius (in Ukrainian).

Rudyk, S.K., Bisiuk, I.Iu. (2000). Istoriia veterynarnoi medytsyny Kyivshchyny. K. Ahrosvit (in Ukrainian).

Sytarchuk, V., (2002). Istoriia veterynarnoi medytsyny Rivnenshchyny. Rivne (in Ukrainian).

Стаття надійшла до редакиії 28.03.2017 